\title{
Assessment of antimicrobial activity of hundreds extract of twenty Indian medicinal plants.
}

\author{
Desh Deepak Singh* \\ Amity Institute of Biotechnology, Amity University, Rajasthan, India
}

\begin{abstract}
The antimicrobial activity of 100 extracts of twenty plants Namely Symplocos racemosa, Solanum xanthocapum, Phyllanthus urinaria, Blumea lacera, Acorus calamus, Thevetia nerifolia, Bauhinia purpurea, Jatropha gossypifolia, Pithecellobium dulce, Hydrangea integrifolia, Sphaeranthus indicus, Vitex negundo, Zizyphus xylopyrus, Aconitum heterophyllum, Scoparia dulcis, Callicarpa dichtoma, Adhatoda zylamei, Sphaeralcea angustifolia, Swertia chirayita, Aconitum heterophyllum from Uttar Pradesh, India was tested against twelve pathogenic micro-organisms. The 51 extracts of $P$. urinaria, $B$. lacera, B. eriantha, T. nerifolia, J. gossypifolia, $P$. dulce, $H$. integrifolia, $S$. indicus, $V$. negundo, $Z$. xylopyrus, A. heterophylum, $S$. dulcis $C$. dichtoma, A. zylamei, S. angustifolia, S. chirayita, A. heterophyllum were found to be inhibiting all the bacterial strains tested, in a range of concentrations by microbroth dilution assay and 0.75 to $48.0 \mathrm{mg} / \mathrm{disc}$ by disc diffusion assay. The 37 extracts were found to be active against the fungal strains in arrange of $0.75 \mathrm{to} 24.0 \mathrm{mg} / \mathrm{ml}$ by microbroth dilution assay. Other plant extracts also exhibited variable antimicrobial activity against one or more species of microorganisms. As the extracts of all the plants which were used in this study effectively controlled the growth of many pathogenic bacteria and fungi, they can be used in the treatment of various infectious diseases. Bioactive compounds from these plants can be employed in the formulation of antimicrobial agents for the treatment of various bacterial and fungal infections.
\end{abstract}

Keywords: Plant extracts, Antifungal, Antimicrobial, Susceptibility testing.

Accepted on January 27, 2018

\section{Introduction}

Inhabitants in rural areas of Uttar Pradesh (India) depend on medicinal plant preparations for treatment of many diseases, including those of infectious by nature [1-3]. People in this region use these plants as a paste or their extracts to cure themselves of various kinds of diseases [2]. Uttar Pradesh is consisting of porous soil. It gets low rainfall and has variable temperature $\left(2.0-48.0^{\circ} \mathrm{C}\right)$, therefore, the region has the characteristic flora of plants [3].
The increasing number of multi-drug resistant microbial strains and the appearance of new strains with reduced susceptibility to antimicrobial raise the spectrum of untreatable infections [4-6]. Therefore, there is need to search new infection-fighting strategies [7,8]. Micro-organisms, animals, and plants are the well-known source of new antimicrobial compounds [9-11]. Systematic screening of the plants which are used to cure various disease conditions in folk fare medicine may result in the discovery of novel effective compounds as shown in Table 1.

Table 1. Selected Indian medicinal used to treat various kinds of human diseases.

\begin{tabular}{|c|c|c|}
\hline S. no. & Name of the plant & medicinal use \\
\hline \multirow[t]{6}{*}{1} & Symplocos racemosa & Tree extracts are beneficial in treating gynecological conditions, like excessive menstrual flow and leukorrhea. \\
\hline & & The extracts of the tree are used to treat digestive disorders like runny stools, diarrhea, dysentery and bloody stools. \\
\hline & & The Bark is given orally with the decoction of Nyagradha (banyan tree) bark. \\
\hline & & The paste should be applied to acne. \\
\hline & & The Powder is recommended for external application which acts as haemostatic remedy. \\
\hline & & The paste of the bark of is applied over the area affected by the localized swelling and wound as treatment. \\
\hline
\end{tabular}


The paste of the bark of the plant is applied over the eyelids to treat conjunctivitis.

The decoction prepared from the bark is given in the divided dose of 50-60 $\mathrm{ml}$ to treat diarrhea and bleeding piles. The decoction constricts the smaller blood vessels and controls bleeding

The cold infusion or decoction is given in a dose of $50-60 \mathrm{ml}$ to treat uterine bleeding disorders.

The cold infusion from the flowers is given in a dose of $30-40 \mathrm{ml}$ to treat a cough and fever

The paste of the bark is applied to treat itching, rashes and insect bite cases.

In cases of discharge from ears, the powder of the bark is sprinkled or blown inside the ear to control the condition.

-The Solanum xanthocarpum has important medicinal properties as follows-

-The paste of the wild eggplant to the feet, it gives you relief from burning sensation.

-Drink the infusion of the eggplant to get instant relief from irritation in the throat.

-The root of the Solanum xanthocarpum, it helps regulate the body temperature.

-The herb helps in fighting viral infections and fever.

-People use the decoction as a mouthwash.

-Villagers used to treat ringworm infections with the wild eggplant because it has antifungal properties. Apply the paste of the root on the affected area for one week.

-The Solanum xanthocarpum has plenty of antioxidants that fight the free radicals. This helps in preventing the incidence of cancer.

-Anti-inflammatory nature

-Helps decrease the glycaemic load;

-Anti-fertility agent: The wild eggplant is capable of destroying the fertility,

-Anthelmintic nature: You can remove the worms in your intestine by the use of the decoction of the wild eggplant. Antirheumatic: It is effective if you use the paste of the root.

-Good form of an appetiser: it is an effective appetizer as it improves the hunger.

-Relieves constipation: the decoction of the wild eggplant to treat constipation

-Useful stomachic: the wild eggplant proves to be a good stomachic. Removes the phlegm from the chest: This is very useful for removing the mucus from the chest and thus promoting good comfortable breathing.

-the health of the bladder: It helps healthy urination and prevents infections.

-Good for the blood circulation

-Treatment for hyperactivity: hyperactivity disorder can get relief by having wild eggplant

-Has plenty of nutrition: the wild eggplant has alkaloid, glycosides, sterols, amino acids, fatty acids, saponins, and more. You can isolate many useful substances such as linoleic acid, oleic acid, flavonoid, apigenin, solanine, lysine, lupeol, and more. Anti-fertility substance solasodine and anti-snail substance solamargine are got from this plant.

-Clears the respiratory passage: The extract of the plant is used to cure a cold, bronchitis, asthma, throat infections, and cough. Read how to cure asthma.

-Antipyretic nature.

-Good for the liver: The wild eggplant supports the health of the liver

-Relieves muscular pain

-Helps in releasing the gas.

- Relieves toothaches: the extract of the leaf helps you get relief from toothaches.

-Clears acne and pimples: paste of the leaves on the face, it will clear the acne and pimples on your face.

-Good for women: It helps regularize menstruation and helps make the delivery easy for women.

-Cure gonorrhoea: the paste of the berries to the genitals to cure gonorrhea.

-Use as an antidote: Snakebites using Solanum xanthocarpum paste. Apply it to the bite. 


\begin{tabular}{|c|c|c|}
\hline & & -Improve the condition of the scalp \\
\hline & & $\begin{array}{l}\text {-Beware usage of Solanum xanthocarpum plant since it has a toxic nature. Even then, the Ayurvedic benefits are } \\
\text { plentiful. Only those who have knowledge of Ayurveda should attempt to make medicinal preparations of Kantkari } \\
\text { plant. }\end{array}$ \\
\hline \multirow[t]{5}{*}{3} & \multirow[t]{5}{*}{ Phyllanthus urinaria } & $\begin{array}{l}\text {-Main uses for kidney stones and gallstones (active stones and as a preventative) to tone, balance, strengthen, } \\
\text { detoxify and protect the liver (and to balance liver enzymes). }\end{array}$ \\
\hline & & -Uses for viruses, including hepatitis A-C, herpes, and HIV. \\
\hline & & -The herb clears the liver, benefits the vision and expels parasites. \\
\hline & & $\begin{array}{l}\text {-It is used for the treatment of many different problems such as Hepatitis, jaundice, Gallstones, Urinary tract infection, } \\
\text { nephretic edema, urinary stones, enteritis and diarrhea, swollen and inflamed rectum, prostatitis, gonorrhea, syphillis, } \\
\text { vaginitis, asthma, bronchitis, cough, tuberculosis, fever, influenza, digestive pain, joint pain, conjunctivitis, anemia. }\end{array}$ \\
\hline & & $\begin{array}{l}\text {-It is used in many herbal products produced which have benefits like helping to soothe the liver and in the } \\
\text { detoxification of the liver. }\end{array}$ \\
\hline \multirow[t]{11}{*}{4} & \multirow[t]{11}{*}{ Blumea lacera } & $\begin{array}{l}\text {-The fresh juice of the leaves of the plant Kukundara is installed as 'Nasya' (Nasal drops) in cases of rhinitis and } \\
\text { headache due to sinusitis. }\end{array}$ \\
\hline & & -The fresh juice of the leaves of Blumea lacera is put as eye drops in cases of conjunctivitis. \\
\hline & & -The leaves of the plant are slightly heated and applied to the area affected with localized swelling. \\
\hline & & $\begin{array}{l}\text {-The fresh juice of Kukundara leaf is used as drops or the leaf is made in to the paste and applied over wound } \\
\text { associated with pus. }\end{array}$ \\
\hline & & -In case of external pile mass, the paste of the leaf is made in to the paste and applied over the area having pile mass. \\
\hline & & $\begin{array}{l}\text {-In case of internal piles, small tablet is prepared from the paste of the leaf along with powder of black pepper and } \\
\text { given internally. }\end{array}$ \\
\hline & & $\begin{array}{l}\text {-The decoction from the leaf and root of Blumea lacera is given in a dose of } 30-40 \mathrm{ml} \text { to treat intestinal worms and } \\
\text { cases of an enlarged liver. }\end{array}$ \\
\hline & & -Gargling is done from the decoction of the root of Kukundara to treat oral ulcers and gingivitis. \\
\hline & & $\begin{array}{l}\text {-The decoction of the root of Blumea lacera is given in a dose of } 45-50 \mathrm{ml} \text { to treat cases of fever, leucorrhea and } \\
\text { cough. }\end{array}$ \\
\hline & & -In cases of the dog bite, the fresh juice of root is administered in a dose of $10 \mathrm{ml}$. \\
\hline & & -Adverse effect: No adverse effect is reported or known after the usage of Kukundara. \\
\hline \multirow[t]{7}{*}{5} & \multirow[t]{7}{*}{ Acorus calamus } & -Extract of $A$. calamus use in cold and cough. \\
\hline & & $\begin{array}{l}\text {-Leaves extract has wound-healing capacity. The extract, prepared as an ointment, promoted wound-healing activity in } \\
\text { rats and it was suggested. }\end{array}$ \\
\hline & & -Known to sooth the nerves and increase meditative concentration, \\
\hline & & -Calamus is also used as a rejuvenation tonic. \\
\hline & & $\begin{array}{l}\text {-Homeopathic decoctions of the root are commonly used for stomach and intestinal troubles, digestive problems, and } \\
\text { cramps. }\end{array}$ \\
\hline & & $\begin{array}{l}\text {-Sweet flag root is good for colds (throat, chest and head), bronchitis and headaches. It is known to calm, if not } \\
\text { completely cure, a sore throat with its antibacterial properties. }\end{array}$ \\
\hline & & $\begin{array}{l}\text { - Chewing the root not only fights infection (especially in throat colds) but it also has a stimulant effect, helping one to } \\
\text { overcome the fatigued feeling that accompanies a cold }\end{array}$ \\
\hline \multirow[t]{5}{*}{6} & \multirow[t]{5}{*}{ Thevetia nerifolia } & -Barks and seeds are cardiac tonic and strong cardiac stimulant. \\
\hline & & -Bark is cathartic, powerful febrifuge and emetic; useful in various kinds of intermittent fevers. \\
\hline & & $\begin{array}{l}\text {-Leaves also possess purgative and emetic properties. Seeds are abortifacient; used for suicidal and homicidal } \\
\text { purposes. }\end{array}$ \\
\hline & & $\begin{array}{l}\text {-Seed oil is emetic and purgative. Plant used in the treatment of external wounds, infected area, ring worms, tumours } \\
\text { etc. antioxidant and anti-inflammatory potentials could be important strategies in defining potent wound healing drug. }\end{array}$ \\
\hline & & -it is used medicinally throughout the tropics in spite of its toxicity. \\
\hline
\end{tabular}




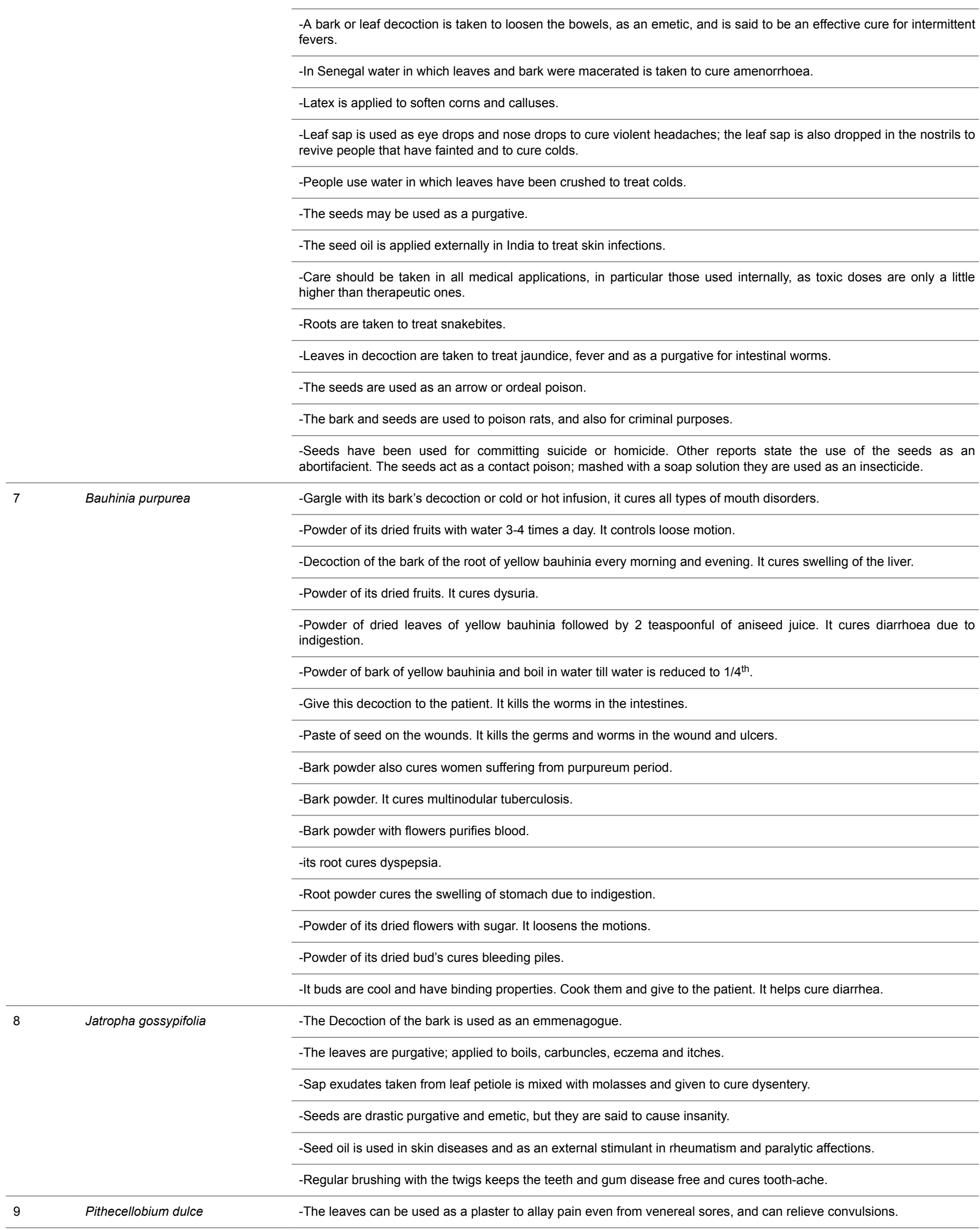




\begin{tabular}{|c|c|c|}
\hline & & \\
\hline & & -A paste made from the leaves is applied externally to treat muscular swellings caused by some inflammations. \\
\hline & & -The leaves together with salt can cure indigestion and, in larger doses, can also induce abortion. \\
\hline & & -The bark of the root is a good remedy for diarrhoea and dysentery. \\
\hline & & -The bark is used medicinally as a febrifuge. \\
\hline & & -The fruit pulp is taken orally to stop blood flow in case of haemoptysis. \\
\hline & & $\begin{array}{l}\text {-The seed juice is inhaled into the nostrils against chest congestion and pulverised seeds are ingested for internal } \\
\text { ulcers. }\end{array}$ \\
\hline & & $\begin{array}{l}\text {-Fruits help boost the immune system, prevent stroke, lessens phlegm, fight cancer, brain functioning hair and skin } \\
\text { health, appetite enhancement, as well as cholesterol control. }\end{array}$ \\
\hline & & -helps in maintaining a healthy stress level. \\
\hline & & -Its Phosphorous content help restore one's body. \\
\hline & & -Its Iron content helps fight fatigue and treat anemia. \\
\hline & & $\begin{array}{l}\text {-Despite its benefits, however, pregnant women should avoid consuming the fruit because of its abortifacient property. } \\
\text { Regular consumers should also note that mild throat irritations may be caused by white-colored Manila Tamarinds. }\end{array}$ \\
\hline 10 & Hydrangea integrifolia & -The root has long been used as a mild diuretic. \\
\hline & & -It has a reputation for helping to prevent and remove gravel, gallbladder stones, and kidney stones. \\
\hline & & $\begin{array}{l}\text {-Will relieve chronic rheumatism, backache, paralysis, scurvy, and dropsy. Homeopathically, for bronchitis, treats } \\
\text { diabetes, incontinence of urine, and prostatic affections. }\end{array}$ \\
\hline & & $\begin{array}{l}\text {-Indians used this herb for urinary retention and stones. As excellent for chronic penile discharge (non-specific } \\
\text { urethritis) in men and mucousal irritation in the aged. }\end{array}$ \\
\hline & & $\begin{array}{l}\text {-This herb acts differently in different people. In some it acts like a laxative. Therefore, it is better to start with a smaller } \\
\text { dose and increase slowly as needed. The average dose is } 2 \text { capsules a day. }\end{array}$ \\
\hline 11 & Sphaeranthus indicus & -The paste of the plants of Mundi is prepared and applied over the area affected with localized swelling. \\
\hline & & $\begin{array}{l}\text {-The fresh juice of the plant is given with black pepper powder in a dose of } 10-15 \mathrm{ml} \text { to treat headache including cases } \\
\text { of migraine. }\end{array}$ \\
\hline & & $\begin{array}{l}\text {-The decoction prepared from the plant is given in a dose of } 50-60 \mathrm{ml} \text { to treat cases of indigestion, piles, intestinal } \\
\text { worms and enlargement of liver. }\end{array}$ \\
\hline & & -The paste of the plant is applied over the area affected with elephantiasis. \\
\hline & & -The cold infusion of Mundi is given in a dose of $40-50 \mathrm{ml}$ to treat chronic cough and asthma. \\
\hline & & -The juice of the plant is given as a nevine tonic and to treat cases of general debility and epilepsy. \\
\hline & & -The paste of the whole plant is applied externally in skin diseases and herpes. \\
\hline & & -Leaves extract as a potent medicine to treat cases of asthma. \\
\hline & & -The cold infusion of the plant is given in a dose of $50-60 \mathrm{ml}$ to treat cases of burning micturition and pyuria. \\
\hline & & $\begin{array}{l}\text {-The decoction prepared from the plant Sphaeranthus indicus is given in a dose of } 40-50 \mathrm{ml} \text { to treat cases of diarrhea } \\
\text { and vomiting. }\end{array}$ \\
\hline & & $\begin{array}{l}\text {-Uses as a in Ayurvedic system of medicine to treat vitiated conditions of epilepsy, mental illness, hemicrania, jaundice, } \\
\text { hepatopathy, diabetes, leprosy, fever, pectoralgia, cough, gastropathy, hernia, hemorrhoids, helminthiasis, dyspepsia } \\
\text { and skin diseases. }\end{array}$ \\
\hline & & $\begin{array}{l}\text {-There are reports providing scientific evidences for hypotensive, anxiolytic, neuroleptic, hypolipidemic, } \\
\text { immunomodulatory, antioxidant, anti-inflammatory, bronchodialatory, antihyperglycemic and hepatoprotective activities } \\
\text { of this plant. }\end{array}$ \\
\hline 12 & Vitex negundo & -Acting to relieve pain. \\
\hline & & - Antiparasitic, expel parasitic worms (helminths) and other internal parasites from the body. \\
\hline & & $\begin{array}{l}\text {-Androgen antagonists or testosterone blocker drug, counteract the effects of the male sex hormones, testosterone } \\
\text { and dihydrotestosterone. }\end{array}$ \\
\hline & & -Treat or prevent asthma attacks. \\
\hline
\end{tabular}




\begin{tabular}{|c|c|c|}
\hline & -Remove excess mucous from the body. \\
\hline & & -Reducing inflammation by acting on body mechanisms. \\
\hline & & -Active against microbes. \\
\hline & & -Improves appetite. \\
\hline & & -Preventing the formation or causing the expulsion of flatulence. \\
\hline & & -Agent or process that disperses a tumour or lesion. \\
\hline & & -Stimulates or increases menstrual flow. \\
\hline & & -Prevent damage to the liver. \\
\hline & & -Kills mosquito larva. \\
\hline & & -Relax or reduce tension in muscle. \\
\hline & \multirow[t]{25}{*}{ Zizyphus xylopyrus } & -Stem bark used in stomachache \\
\hline & & -Cholera stem bark paste is made into pills and taken orally. \\
\hline & & -Root bark Bleeding of piles as well as from nose and mouth root bark powder of Z. xylopyrus Willd \\
\hline & & -Skin rashes bark is boiled with water; water is used to bath for curing skin rashes \\
\hline & & -Fruit diabetic fruits powder is taken orally with milk for $5 \mathrm{~d}$ \\
\hline & & -Stomachache fruit powder (3-4 g) along with pinch of ginger powder taken orally thrice in a day \\
\hline & & -Urinary spasm fresh fruits crushed with water and taken twice a day \\
\hline & & $\begin{array}{l}\text {-Sterility in women's: the crushed fruit powder is soaked in water and kept overnight (macerate, decoction) and this } \\
\text { extract is taken by the women early in the morning for } 7 \mathrm{~d} \text { to check oogenesis. }\end{array}$ \\
\hline & & -Diarrhoea fruits and bark are used in the treatment of diarrohea. \\
\hline & & -Leaves and flowers urinary problem leaves are chewed for $15 \mathrm{~d}$ in case of urinary problem \\
\hline & & $\begin{array}{l}\text {-Pimples and boils leaf paste is applied on pimples while leaves are ground along with latex of Ipomea carnea applied } \\
\text { on boils. }\end{array}$ \\
\hline & & $\begin{array}{l}\text {-Snake bites decoction of Muraya koenigii Spreng (stem bark), Terminalia bellerica Roxb (leaves) and Z. xylopyrus } \\
\text { Retz. (Leaves) were taken internally. Leucoderma paste of Z. xylopyrus leaves and flowers of Datura innoxia was } \\
\text { applied on patches at night till relief. }\end{array}$ \\
\hline & & $\begin{array}{l}\text {-Leaves and stems Hysteria, antidote for fox, antiseptic, headache-root asthma Z. xylopyrus roots were crushed along } \\
\text { with stem barks of Calotropis gigantea. }\end{array}$ \\
\hline & & -Pyorrhoea and bristles used in pyorrhoea and to check oogenesis. \\
\hline & & $\begin{array}{l}\text {-Seed pain after cough and cold: the roasted seed powder paste is applied over the chest for relieving the pain after } \\
\text { cough and colds. }\end{array}$ \\
\hline & & -The dried seeds powder are used to treat diarrhea \\
\hline & & -Leaf powder stimulates sexual desire. \\
\hline & & -Areal part active against microbes. \\
\hline & & -Seed powder reducing inflammation by acting on body mechanisms. \\
\hline & & -Reducing sensitivity to painful stimuli. \\
\hline & & -Leaves and Flowers prevent or reduce the severity of epileptic fits or other convulsions. \\
\hline & & -Seed powder inhibits the production of steroid hormones. \\
\hline & & -Leaves and flowers relieving or preventing diarrhea. \\
\hline & & -Seed powder birth control. \\
\hline & & -Seed powder help in heals wounds. \\
\hline 14 & & -The juice of roots along with milk is an expectorant root po \\
\hline
\end{tabular}




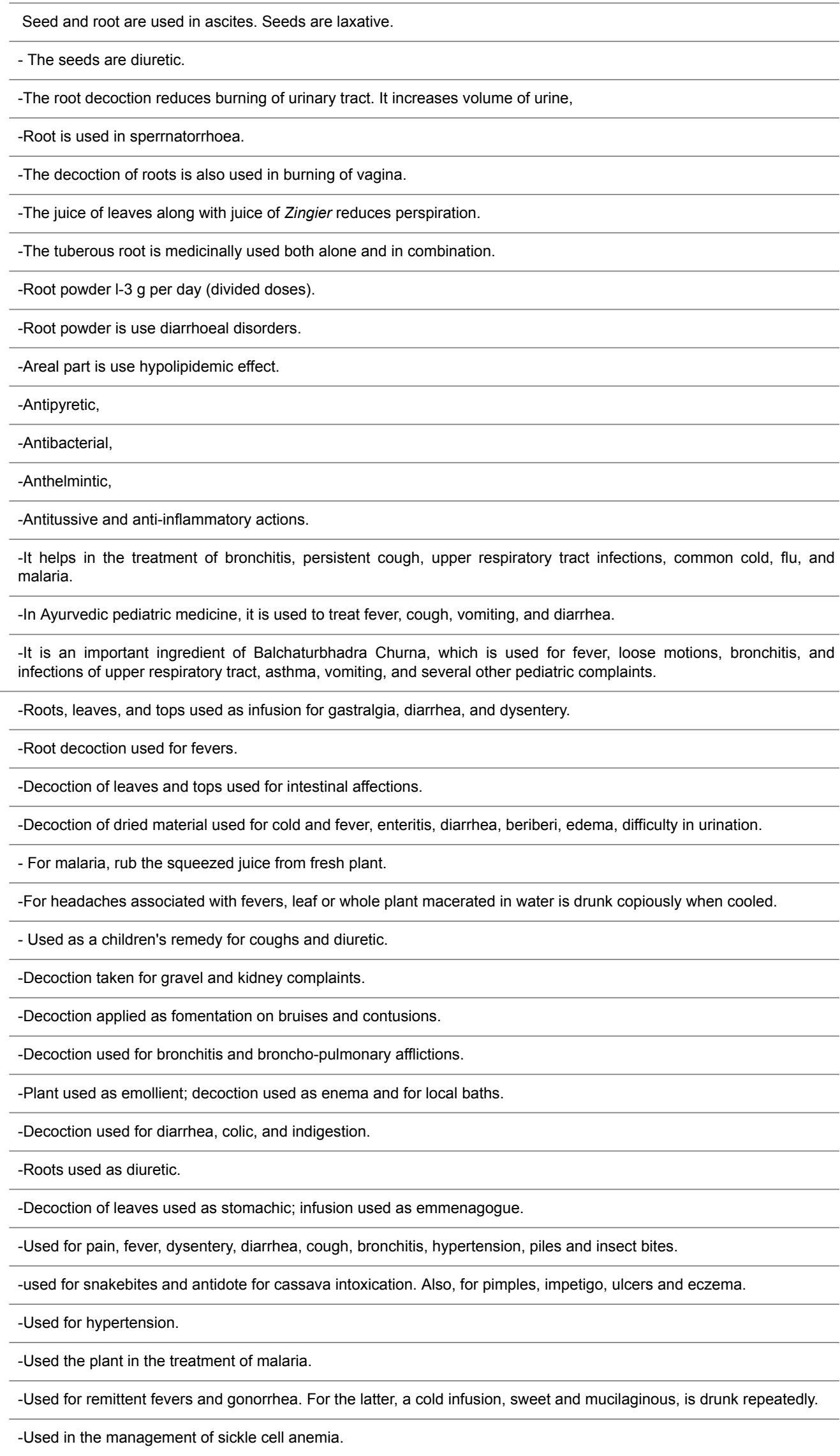




\begin{tabular}{|c|c|c|}
\hline & & \multirow{2}{*}{-Plant used for malaria. } \\
\hline & & \\
\hline & & -Used for gonorrhea, to induce labor, and diabetes. \\
\hline & & -leaves ground to a paste applied topically for wound healing. \\
\hline & & -Used for herpes. \\
\hline & & -Herb infusion used as mouthwash for infected gums. \\
\hline & & -Laves used for stomach ache and venereal diseases. \\
\hline & & -Used for bronchitis, gastric disorders, hemorrhoids, insect bites, skin wound \\
\hline \multirow[t]{10}{*}{16} & \multirow[t]{10}{*}{ Callicarpa dichtoma } & $\begin{array}{l}\text {-The roots, leaves, and branches were used by various Native American tribes for medicinal purposes to treat malarial } \\
\text { fevers and rheumatism. }\end{array}$ \\
\hline & & -The roots are used to treat dizziness, stomachaches and dysentery. \\
\hline & & -Roots and berries are boiled and drunk to treat colic. \\
\hline & & -Farmers would crush the leaves and place them under the harnesses of horses and mules to repel mosquitoes. \\
\hline & & -The farmers rubbed the crushed leaves on themselves to repel mosquitoes and biting bugs. \\
\hline & & $\begin{array}{l}\text {-The beauty berry plant has been a traditional folk remedy for repelling mosquitoes, horseflies, deerflies, ticks, and } \\
\text { other biting insects for over a century. }\end{array}$ \\
\hline & & -Antipyretic, \\
\hline & & -Antibacterial, anthelmintic, antitussive and antiinflammatory actions. \\
\hline & & $\begin{array}{l}\text {-It helps in the treatment of bronchitis, persistent cough, upper respiratory tract infections, common cold, flu, and } \\
\text { malaria. In ayurvedic pediatric medicine, it is used to treat fever, cough, vomiting, and diarrhea. }\end{array}$ \\
\hline & & $\begin{array}{l}\text {-It is an important ingredient of Balchaturbhadra Churna, which is used for fever, loose motions, bronchitis, and } \\
\text { infections of upper respiratory tract, asthma, vomiting, and several other pediatric complaints. }\end{array}$ \\
\hline \multirow[t]{13}{*}{17} & \multirow[t]{13}{*}{ Adhatoda zylamei } & $\begin{array}{l}\text {-Anti-asthmatic and bronchodilator activity Adhatoda has been used in traditional medicine to treat respiratory } \\
\text { disorders. Both vasicine and vasicinone the primary alkaloid constituents of Adhatoda are well established as } \\
\text { therapeutical respiratory agents. }\end{array}$ \\
\hline & & $\begin{array}{l}\text {-Extracts of Adhatoda's leaves and roots are useful in treating bronchitis, and other lung and bronchiole disorders, as } \\
\text { well as common coughs and colds. }\end{array}$ \\
\hline & & $\begin{array}{l}\text {-A decoction of the leaves of Adhatoda has a soothing effect on irritation in the throat, and acts as an expectorant to } \\
\text { loosen phlegm in the respiratory passages. }\end{array}$ \\
\hline & & $\begin{array}{l}\text {-To evaluate the antitussive activities of Adhatoda extract in anesthetized guinea pigs and rabbits and in } \\
\text { unanesthetized guinea pigs showed the plant to have a good antitussive activity. }\end{array}$ \\
\hline & & -Recent investigations using vasicine showed bronchodilatory activity both in vitro and in vivo. \\
\hline & & -Wound healing activity \\
\hline & & -Anti-ulcer activity \\
\hline & & -Cholagogue activity \\
\hline & & -Anti-allergy activity \\
\hline & & -Anti-tubercular activity \\
\hline & & -Abortifacient and uterotonic activity \\
\hline & & -Insecticidal activity \\
\hline & & -Anti-bacterial activity \\
\hline \multirow[t]{3}{*}{18} & \multirow[t]{3}{*}{ Sphaeralcea angustifolia } & $\begin{array}{l}\text {-The leaves of Sphaeralcea coccinea are utilized in lotions to relieve skin diseases, or the fresh mashed leaves are } \\
\text { employed }\end{array}$ \\
\hline & & -as poultices on inflamed skin, sores and wounds. \\
\hline & & $\begin{array}{l}\text {-Leaves used as an anti-inflammatory and wound-healing remedy. The fresh plant is topically applied as a poultice that } \\
\text { covers the affected tissue; sometimes, dietary oil is added to the plant. }\end{array}$ \\
\hline
\end{tabular}




\begin{tabular}{|c|c|c|}
\hline & & \multirow{2}{*}{$\begin{array}{l}\text {-The decoction of the aerial parts of } S \text {. angustifolia in combination with other medicinal species is administered orally } \\
\text { for the treatment of stomachache and diarrhea and the root has been reported for treating bladder disorders. }\end{array}$} \\
\hline & & \\
\hline \multirow[t]{15}{*}{19} & \multirow[t]{15}{*}{ Swertia chirayita } & -All parts of the plants can be used for making either a dried herb or powder. \\
\hline & & -Areal part is well -known for swiftly lowering fevers from colds and flues. \\
\hline & & $\begin{array}{l}\text {-Leaves powder is great for rashes, inflamed skin, and other types of skin problems. Also works well when mixed with } \\
\text { water for wound cleansing and healing and it's great for oozing skin. }\end{array}$ \\
\hline & & $\begin{array}{l}\text {-Areal part is a powerful anti-inflammatory agent making it great for joint disease, swelling, pain, and redness. Swerita } \\
\text { is particularly good for rheumatoid arthritis. }\end{array}$ \\
\hline & & -used for treating liver problems, and also does a good job of detoxing the liver. \\
\hline & & -Leaves extract also increases metabolism thus helping with weight loss. \\
\hline & & -Leaves powder is great for helping those who suffer from constipation. \\
\hline & & $\begin{array}{l}\text {-Areal part has the ability to lower blood sugar, studies with rats given Swertia chirata show blood sugar was greatly } \\
\text { reduced. Swerita stimulates insulin production in pancreatic cells thus lowering blood sugar naturally and it may be a } \\
\text { cure for diabetes. }\end{array}$ \\
\hline & & -Extract pf areal part can help the body produce more red blood cells like many different types of bitter herbs. \\
\hline & & $\begin{array}{l}\text {-Swerita works well for soothing away stomach-aches, nausea, GI upsets, gas, bloating, diarrhea, and inflammation of } \\
\text { the intestines. Rats with gastric ulcers significantly improved when given Swerita because it slows the production of } \\
\text { acids in the stomach. }\end{array}$ \\
\hline & & -Swerita helps with heavy monthly periods, internal bleeding, and nose bleeds. \\
\hline & & -Swerita helps with bronchitis, asthma, and inflammatory conditions of the lungs by opening up the bronchi. \\
\hline & & $\begin{array}{l}\text {-Swerita contains powerful antioxidant compounds that help to slow the aging process, repair DNA damage, plus } \\
\text { prevent cardiovascular disease, strokes, and cancer. }\end{array}$ \\
\hline & & $\begin{array}{l}\text {-Swerita has the ability to protect against cancer because of powerful antioxidant compounds that stop the progression } \\
\text { of precancerous lesions. especially liver cancer. }\end{array}$ \\
\hline & & -Swerita is a very good antiviral compound that helps with herpes and possibly papilloma virus. \\
\hline
\end{tabular}

Antimicrobials of plant origin have minimum side effects and have an enormous therapeutic potential to heal many infectious diseases [7]. Out of all, 83\% drugs in the present market are related to the natural product therefore, natural product is gaining important to treat these microbial infections or to find out new drugs to treat these infections which have the least side effects.

In the present study, various extracts of ten plants from different families were tested against microbial pathogens. The plant species tested were Symplocos racemosa, Solanum xanthocapum, Phyllanthus urinaria, Blumea lacera, Acorus calamus, Thevetia nerifolia, Bauhinia purpurea, Jatropha gossypifolia, Pithecellobium dulce, Hydrangea integrifolia, Sphaeranthus indicus, Vitex negundo, Zizyphus xylopyrus, Aconitum heterophyllum, Scoparia dulcis, Callicarpa dichtoma, Adhatoda zylamei, Sphaeralcea angustifolia, Swertia chirayita, Aconitum heterophyllum. All these plants have their own medicinal importance in the life of rural natives of Uttar Pradesh to treat various kinds of infections.

\section{Materials and Methods}

\section{Plant materials}

The aerial parts of plants tested were collected from different region of the Uttar Pradesh from the months of October 2012-
December 2016. The plant material was dried in shade and used to prepare different extracts.

\section{Preparation of plant extracts}

The powdered material of plants was subjected to Soxhlet extraction successively with n-hexane, chloroform, acetone, methanol and water to obtain respective fractions [10]. Solvents were evaporated under reduced pressure using rotavapor and dry fractions were stored at $4^{\circ} \mathrm{C}$ till use.

\section{Micro-organisms}

Clinical isolates of Aspergillus, Candida and bacterial strains namely, A. fumigatus (190/96), A. flavus (223/96), A. niger (56/96), C. albicans (345/96), Salmonella typhi (135/98), Escherichia coli (576/98), Staphylococcus aureus (231/98), Pseudomonas aeruginosa (87/98), Streptomyces pyogene (124/98), Enterobater aerogenes (248/98), Bacillus cereus (272/98) and Klebsiella pneumonae (31/98) from the Microbiology Department, Vallabhbhai Patel Chest Institute, Delhi were used along with the standard strains. Quality control strains of A. fumigatus ITCC 4517, A. flavus ITCC 5192, A. niger ITCC 5405, C. albicans ITCC 4718 obtained from Indian Type Culture Collection, IARI, Delhi. S. typhi MTCCB 733, E. coli MTCCB 82, S. aureus MTCCB 737, $P$. aeruginosa MTCCB 741, S. pyogenes MTCCB 655, E. 
aerogenes MTCCB 111, B. cereus MTCCB 1272, K. pneumonae MTCCB 109 were included in each test as recommended by the National Committee for Clinical Laboratories Standards (NCCLS) were purchase from Institute of Microbiology Technology, Chandigarh, India.

\section{Antimicrobial activity}

Antimicrobial activity of the various extracts of different plants was determined by the Micro broth dilution Assay as per described in NCCLS document M-27A (NCCLS), 2011 [12]. The fungi and bacterial strains used as inoculum were grown overnight on Sabouraud dextrose agar and nutrient agar respectively at $37^{\circ} \mathrm{C}$. Lowest concentration which inhibited any visual growth was considered to be Minimum Inhibitory Concentration (MIC).

\section{Test of antibacterial activity}

All the extracts were prepared in a concentration ranging from 0.750 to $48.0 \mu \mathrm{g} / \mathrm{ml}$. Proper controls were used for each experiment. The bacterial strains used as inoculum were grown at $37^{\circ} \mathrm{C}$ to get OD 0.6 at $600 \mathrm{~nm}$ and used for susceptibility testing. The lowest concentration, which inhibited any visual growth, was considered to be Minimum Inhibitory Concentration (MIC).

\section{Antifungal activity}

The susceptibility testing of Aspergillus strains was determined by the microbroth dilution method. Cultures were grown on Sabouraud dextrose agar at $37^{\circ} \mathrm{C}$ until sporulation occurs, typically $5 \mathrm{~d}$. Stock spores' suspensions were with yeast nitrogen or broth ( $\mathrm{pH} 7.0$ ) supplemented with $5.0 \mathrm{~g}$ glucose per liter and $24 \%(\mathrm{vol} / \mathrm{vol})$ glycerol and were stored at $4{ }^{\circ} \mathrm{C}$ until use. The numbers of Colony Forming Units (CFU) per milliliter were determined by plating serial dilutions on Sabouraud dextrose agar plates. For susceptibility tests, the spore suspensions were diluted to achieve $2 \times 10^{4}$ to $2 \times 10^{5}$ $\mathrm{CFU} / \mathrm{ml}$ in yeast nitrogen broth plus $0.5 \%$ glucose $(\mathrm{Ph} 7.0)$ and were incubated for $24 \mathrm{~h}$ at $35^{\circ} \mathrm{C}$ to germinate spores. Serial twofold dilution of extracts was made in yeast nitrogen broth plus $0.5 \%$ glucose $(\mathrm{pH} 7.0)$ in a concentration ranging from 0.75 to $48.0 \mathrm{mg} / \mathrm{disc}$. The cultures were incubated for $48 \mathrm{~h}$ at $37^{\circ} \mathrm{C}$. MICs were determined at the lowest concentration that inhibited visible fungal growth. Disc diffusion assay was performed as per Indian Pharmacopeia (1996) [13] against pathogenic strains of microorganisms and lowest concentration which forms a zone of inhibition about $6.5 \mathrm{~mm}$ (Disc diameter was $6.0 \mathrm{~mm}$ ) was considered to MIC by disc diffusion assay in this paper [10].

\section{Results and Discussion}

The differences among various antimicrobial effects of plant groups are natural depending upon the phytochemical properties of plants and antimicrobial nature of plant metabolites [10]. Uttar Pradesh due to its typical environmental conditions (Temperature to $47^{\circ} \mathrm{C}$ and average rainfall) [1,2] and characteristic flora provides rich source of plant materials [11]. The region also has a history of the application of plants in folklore medicines.

100 different extracts of twenty plants used in this study to evaluate their antimicrobial potential against $S$. typhi, E. coli, $S$. aureus, $P$. aeruginosa, $S$. pyogenes, E. aerogenes, B. cereus, $K$. pneumonae $C$. albicans, $A$. niger, A. fumigatus, and $A$. flavus using micro-broth dilution as shown in Table 2 as well as disc diffusion assays Table 3 .

Table 2. Minimum inhibitory concentration of plant extracts against the microorganisms by micro dilution broth assay.

\begin{tabular}{|c|c|c|c|c|c|c|c|c|c|c|c|c|}
\hline \multirow[t]{2}{*}{ Name of the plant } & \multicolumn{12}{|c|}{ Minimum inhibitory concentration $(\mathrm{mg} / \mathrm{ml})$} \\
\hline & A & B & C & D & $E$ & $\mathbf{F}$ & G & $\mathbf{H}$ & 1 & $\mathbf{J}$ & $\mathbf{K}$ & $\mathbf{L}$ \\
\hline \multicolumn{13}{|l|}{ Symplocos racemosa } \\
\hline Water Ext & 0.75 & 1.52 & 0.75 & 0.75 & 1.5 & 0.75 & 0.75 & 0.75 & 1.5 & 1.5 & 2.5 & 1.5 \\
\hline Methanol Ext & 6 & - & 6 & - & 3 & - & 6 & 6 & 3 & 3 & 3 & 1.5 \\
\hline Acetone Ext & - & - & 3 & 3 & 3 & 3 & 6 & 3 & - & - & - & - \\
\hline Chloroform Ext & - & 3 & 3 & 3 & - & - & - & 6 & 12 & 12 & -12 & \\
\hline \multicolumn{13}{|l|}{ S. xanthocapum } \\
\hline Water Ext & - & 6 & 3 & 3 & 3 & 6 & 3 & 6 & 12 & 12 & 24 & 24 \\
\hline Methanol Ext & 6 & - & 6 & - & 3 & - & 6 & 6 & 3 & 3 & 3 & 1.5 \\
\hline Acetone Ext & - & - & 3 & 3 & 3 & 3 & 6 & 3 & 12 & 12 & 12 & 24 \\
\hline Chloroform Ext & 6 & 3 & 3 & 3 & - & - & - & 6 & 12 & 12 & 24 & 24 \\
\hline Hexane Ext & - & - & 3 & 3 & 3 & - & 3 & 3 & 3 & 3 & 3 & 3 \\
\hline
\end{tabular}


Assessment of antimicrobial activity of hundreds extract of twenty Indian medicinal plants

\begin{tabular}{|c|c|c|c|c|c|c|c|c|c|c|c|c|}
\hline Water Ext & - & - & - & - & - & - & - & - & - & - & - & - \\
\hline Methanol Ext & 3 & 3 & 3 & 1.5 & 3 & 3 & 1.5 & 1.5 & 12 & 12 & 24 & 24 \\
\hline Acetone Ext & 1.5 & 3 & 3 & 1.5 & 3 & 3 & 3 & 3 & 12 & 12 & 24 & 24 \\
\hline Chloroform Ext & - & - & - & - & - & - & - & - & - & - & - & - \\
\hline Hexane Ext & - & - & - & - & - & - & - & - & - & - & - & - \\
\hline \multicolumn{13}{|l|}{ B. lacera } \\
\hline Water Ext & 1.5 & 3 & 1.5 & 3 & 3 & 1.5 & 1.5 & 3 & - & - & - & 24 \\
\hline Methanol Ext & 6 & 6 & 3 & 6 & 6 & 3 & 6 & 6 & 12 & 12 & 24 & 24 \\
\hline Acetone Ext & 1.5 & 1.5 & 3 & 3 & 3 & 1.5 & 1.5 & 3 & - & - & - & - \\
\hline Chloroform Ext & - & - & - & - & - & - & - & - & - & - & - & - \\
\hline Hexane Ext & - & - & - & - & - & - & - & - & 24 & 24 & - & 24 \\
\hline \multicolumn{13}{|l|}{ B. eriantha } \\
\hline Water Ext & 0.75 & 3 & 1.5 & 3 & 3 & 1.5 & 1.5 & 3 & - & - & - & 12 \\
\hline Methanol Ext & 6 & 6 & 3 & 6 & 12 & 6 & 12 & 3 & - & - & - & - \\
\hline Acetone Ext & 1.5 & 1.5 & 6 & 3 & 3 & 1.5 & 3 & 1.5 & - & - & - & - \\
\hline Chloroform Ext & - & 1.5 & - & - & - & - & - & - & - & - & - & - \\
\hline Hexane Ext & - & - & - & - & - & - & - & - & 12 & 24 & - & 12 \\
\hline \multicolumn{13}{|l|}{ T. nerifolia } \\
\hline Water Ext & 1.5 & 1.5 & 0.75 & 3 & 0.75 & 1.5 & 1.5 & 1.5 & - & - & - & - \\
\hline Methanol Ext & 3 & 6 & 1.5 & 3 & 3 & 3 & 3 & 6 & 12 & 12 & 24 & 24 \\
\hline Acetone Ext & 0.75 & 0.75 & 3 & 3 & 1.5 & 1.5 & 3 & 3 & - & - & - & - \\
\hline Chloroform Ext & - & 3 & - & 3 & - & - & - & - & - & - & - & - \\
\hline Hexane Ext & 3 & - & 3 & - & - & 3 & - & - & 12 & 12 & 24 & 24 \\
\hline \multicolumn{13}{|c|}{ Bauhinia purpurea } \\
\hline Water Ext & - & 6 & 3 & 3 & 3 & 6 & 3 & 6 & 12 & 12 & 24 & 24 \\
\hline Methanol Ext & 6 & - & 6 & - & 3 & - & 6 & 6 & 3 & 3 & 3 & 1.5 \\
\hline Acetone Ext & - & - & 3 & 3 & 3 & 3 & 6 & 3 & 12 & 12 & 12 & 24 \\
\hline Chloroform Ext & 6 & 3 & 3 & 3 & - & - & - & 6 & 12 & 12 & 24 & 24 \\
\hline Hexane Ext & - & - & 3 & 3 & 3 & - & 3 & 3 & 3 & 3 & 3 & 3 \\
\hline \multicolumn{13}{|l|}{ J. gossypifolia } \\
\hline Water Ext & 24 & 24 & 24 & 12 & 24 & 12 & 24 & 12 & 24 & - & - & 24 \\
\hline Methanol Ext & 24 & 24 & 24 & 12 & 24 & 12 & 12 & 24 & 24 & 12 & 24 & 24 \\
\hline Acetone Ext & 24 & 24 & 12 & 12 & 24 & 24 & 24 & 12 & - & - & - & 24 \\
\hline Chloroform Ext & 12 & 12 & 24 & 12 & - & - & 12 & - & - & - & - & 24 \\
\hline Hexane Ext & 12 & 12 & 24 & 12 & 24 & 6 & 12 & 24 & - & - & - & 6 \\
\hline \multicolumn{13}{|l|}{ P. dulce } \\
\hline Water Ext & - & - & - & - & - & - & - & - & - & -- & - & - \\
\hline Methanol Ext & 24 & 24 & 24 & 12 & 24 & 12 & 12 & 24 & 24 & 12 & 24 & 24 \\
\hline
\end{tabular}




\begin{tabular}{|c|c|c|c|c|c|c|c|c|c|c|c|c|}
\hline Acetone Ext & - & - & - & - & - & - & - & - & - & - & - & - \\
\hline Chloroform Ext & 24 & 24 & 24 & 12 & 24 & 12 & 12 & - & - & - & - & - \\
\hline Hexane Ext & - & - & - & - & - & - & - & - & - & - & - & - \\
\hline \multicolumn{13}{|l|}{ H. integrifolia } \\
\hline Water Ext & 12 & 12 & 12 & 3 & 24 & 12 & 12 & 12 & 12 & 12 & 2424.0 & \\
\hline Methanol Ext & 6 & 6 & 3 & 6 & 12 & 6 & 12 & 3 & 6 & 12 & 3 & 24 \\
\hline Acetone Ext & - & - & - & - & - & - & - & - & - & - & - & - \\
\hline Chloroform Ext & 6 & 6 & 3 & 3 & 12 & 6 & 12 & 3 & 12 & 12 & 24 & 24 \\
\hline Hexane Ext & - & - & - & - & - & - & - & - & - & - & - & - \\
\hline Ketoconazole & - & - & - & - & - & - & - & - & - & - & - & - \\
\hline Ampicillin & - & - & - & - & - & - & - & - & - & - & - & - \\
\hline S. indicus & $A$ & B & $\mathrm{C}$ & $\mathrm{D}$ & $E$ & $\mathrm{~F}$ & G & $\mathrm{H}$ & 1 & $\mathrm{~J}$ & $\mathrm{~K}$ & L \\
\hline Water Ext & 0.75 & 1.52 & 0.75 & 0.75 & 1.5 & 0.75 & 0.75 & 0.75 & 1.5 & 1.5 & 2.5 & 1.5 \\
\hline Methanol Ext & - & 1.52 & 6 & - & 3 & - & 6 & 6 & 3 & 3 & 3 & 1.5 \\
\hline Acetone Ext & 6 & 6 & 3 & 6 & 12 & 6 & 12 & 3 & - & - & - & - \\
\hline Chloroform Ext & 0.75 & 1.52 & 0.75 & 0.75 & 1.5 & 0.75 & 0.75 & 0.75 & 1.5 & 1.5 & 2.5 & 1.5 \\
\hline \multicolumn{13}{|l|}{ V. negundo } \\
\hline Water Ext & - & 6 & 3 & 3 & 3 & 6 & 3 & 6 & - & - & - & - \\
\hline Methanol Ext & 6 & 6 & 3 & 6 & 6 & 3 & 6 & 6 & 3 & 3 & 3 & 1.5 \\
\hline Acetone Ext & - & - & 3 & 3 & 3 & 3 & 6 & 3 & - & - & - & - \\
\hline Chloroform Ext & - & 3 & 3 & 3 & - & - & - & 6 & 6 & 12 & 6 & 12 \\
\hline Hexane Ext & 0.75 & 3 & 1.5 & 3 & 3 & 1.5 & 1.5 & 3 & 3 & 3 & 1.5 & - \\
\hline \multicolumn{13}{|l|}{ Z. xylopyrus } \\
\hline Water Ext & - & - & - & - & - & - & - & - & - & - & - & - \\
\hline Methanol Ext & 3 & 3 & 3 & 1.5 & 3 & 3 & 1.5 & 1.5 & 24 & 12 & 24 & 24 \\
\hline Acetone Ext & 1.5 & 3 & 3 & 1.5 & 3 & 3 & 3 & 3 & - & - & - & - \\
\hline Chloroform Ext & - & - & - & - & - & - & - & - & 24 & 12 & 24 & 12 \\
\hline Hexane Ext & 6 & 24 & 24 & 12 & 24 & 12 & 12 & 24 & - & - & - & - \\
\hline \multicolumn{13}{|l|}{ A. heterophylum } \\
\hline Water Ext & 6 & 6 & 3 & 6 & 12 & 6 & 12 & 3 & - & - & - & 24 \\
\hline Methanol Ext & 1.5 & 1.5 & 3 & 3 & 3 & 1.5 & 1.5 & 3 & 1.5 & 1.5 & 1.25 & 1.5 \\
\hline Acetone Ext & 1.5 & 1.5 & 3 & 3 & 3 & 1.5 & 1.5 & 3 & - & - & - & - \\
\hline Chloroform Ext & - & - & - & - & - & - & - & - & - & - & - & - \\
\hline Hexane Ext & - & - & - & - & - & - & - & - & 24 & 24 & - & 24 \\
\hline \multicolumn{13}{|l|}{ S. dulcis } \\
\hline Water Ext & 0.75 & 3 & 1.5 & 3 & 3 & 1.5 & 1.5 & 3 & - & - & - & 12 \\
\hline Methanol Ext & 6 & 6 & 3 & 6 & 12 & 6 & 12 & 3 & - & - & - & - \\
\hline Acetone Ext & 1.5 & 1.5 & 6 & 3 & 3 & 1.5 & 3 & 1.5 & - & - & - & - \\
\hline
\end{tabular}




\begin{tabular}{|c|c|c|c|c|c|c|c|c|c|c|c|c|}
\hline Chloroform Ext & - & 1.5 & - & - & - & - & - & - & - & - & - & - \\
\hline Hexane Ext & - & - & - & - & - & - & - & - & 12 & 24 & - & 12 \\
\hline \multicolumn{13}{|l|}{ C. dichtoma } \\
\hline Water Ext & 1.5 & 1.5 & 0.75 & 3 & 0.75 & 1.5 & 1.5 & 1.5 & - & - & - & - \\
\hline Methanol Ext & 3 & 6 & 1.5 & 3 & 3 & 3 & 3 & 6 & - & - & - & - \\
\hline Acetone Ext & 0.75 & 0.75 & 3 & 3 & 1.5 & 1.5 & 3 & 3 & - & - & - & - \\
\hline Chloroform Ext & 24 & 24 & 24 & 12 & 24 & 12 & 24 & 12 & - & - & - & - \\
\hline Hexane Ext & - & - & - & - & - & - & - & - & - & - & - & - \\
\hline \multicolumn{13}{|l|}{ A. zylamei } \\
\hline Water Ext & 24 & 24 & 24 & 12 & 24 & 12 & 24 & 12 & - & - & - & - \\
\hline Methanol Ext & 3 & 3 & 6 & 1.5 & 3 & 3 & 3 & 3 & 6 & 12 & 24 & 12 \\
\hline Acetone Ext & - & - & - & - & - & - & - & - & - & - & - & - \\
\hline Chloroform Ext & 24 & 24 & 24 & 12 & 24 & 12 & 12 & 24 & - & 12 & 24 & 12 \\
\hline Hexane Ext & -24 & 24 & 24 & 12 & 24 & 12 & 12 & 24 & - & - & - & - \\
\hline \multicolumn{13}{|l|}{ S. angustifolia } \\
\hline Water Ext & 24 & 24 & 24 & 12 & 24 & 12 & 24 & 12 & 12 & 24 & 24 & 24 \\
\hline Methanol Ext & 0.75 & 1.52 & 0.75 & 0.75 & 1.5 & 0.75 & 0.75 & 0.75 & 1.5 & 1.5 & 2.5 & 1.5 \\
\hline Acetone Ext & 24 & 24 & - & 12 & 24 & 24 & 24 & 12 & - & - & - & 24 \\
\hline Chloroform Ext & - & - & 24 & 12 & - & - & 12 & - & - & - & - & 24 \\
\hline Hexane Ext & 12 & 12 & 24 & 12 & 24 & 6 & 12 & 24 & - & - & - & 6 \\
\hline \multicolumn{13}{|l|}{ S. chirayita } \\
\hline Water Ext & - & - & - & - & - & - & - & - & - & - & - & - \\
\hline Methanol Ext & 24 & 24 & 24 & 12 & 24 & 12 & 12 & 12 & 12 & 12 & 24 & 24 \\
\hline Acetone Ext & - & - & - & - & - & - & - & - & - & - & - & - \\
\hline Chloroform Ext & 24 & 24 & 24 & 12 & 24 & 12 & 12 & - & - & - & - & - \\
\hline Hexane Ext & 12 & 3 & 6 & 1.5 & 3 & 3 & 3 & 3 & 6 & 12 & 24 & 12 \\
\hline \multicolumn{13}{|l|}{ A. heterophyllum } \\
\hline Water Ext & 24 & 24 & 24 & 12 & 24 & 12 & 24 & 12 & - & - & - & - \\
\hline Methanol Ext & 3 & 3 & 6 & 1.5 & 3 & 3 & 3 & 3 & 6 & 12 & 24 & 12 \\
\hline Acetone Ext & - & - & - & - & - & - & - & - & - & - & - & - \\
\hline Chloroform Ext & 24 & 24 & 24 & 12 & 24 & 12 & 12 & 24 & - & 12 & 24 & 12 \\
\hline Hexane Ext & 24 & 24 & 24 & 12 & 24 & 12 & 12 & 24 & - & - & - & - \\
\hline
\end{tabular}

Ampicillin

A: S. pyogenes; B: E. coli; C: S. typhi, D: P. aeruginosa; E: S. aureus; F: E. aerogenes; G: B. cereus; H: K. pneumonae; I: A. fumigatus; J: A. flavus; K: A. niger, L: C. albicans. Note: (-) means no activity.

Table 3. Antimicrobial activity of compounds by disc diffusion method. 


\section{A \\ B C \\ D E}

Symplocos racemosa

\begin{tabular}{|c|c|c|c|c|c|c|c|c|c|c|c|c|}
\hline Water Ext & 0.312 & 0.75 & 0.75 & 1.5 & 0.75 & 0.75 & 0.75 & 1.5 & 1.5 & 2.5 & 1.5 & - \\
\hline Methanol Ext & 6 & - & 6 & - & 3 & - & 6 & 6 & 3 & 3 & 3 & 1.5 \\
\hline Acetone Ext & - & - & 3 & 3 & 3 & 3 & 6 & 3 & - & - & - & - \\
\hline Chloroform Ext & - & 3 & 3 & 3 & - & - & - & 6 & 12 & 12 & - & 12 \\
\hline \multicolumn{13}{|l|}{ S. xanthocapum } \\
\hline Water Ext & - & 3 & 3 & 3 & 3 & 6 & 3 & 3 & 6 & 6 & 24 & 24 \\
\hline Methanol Ext & 6 & - & 6 & - & 3 & - & 6 & 3 & 3 & 3 & 3 & 1.5 \\
\hline Acetone Ext & - & - & 3 & 3 & 3 & 3 & 6 & 3 & 6 & 6 & 12 & 24 \\
\hline Chloroform Ext & 6 & 3 & 3 & 3 & - & - & - & 3 & 6 & 6 & 24 & 24 \\
\hline Hexane Ext & - & - & 3 & 3 & 3 & - & 3 & 3 & 3 & 3 & 3 & 3 \\
\hline
\end{tabular}

P. urinaria

Water Ext

\begin{tabular}{|c|c|c|c|c|c|c|c|c|c|c|c|c|}
\hline Methanol Ext & 3 & 3 & 3 & 1.5 & 3 & 3 & 1.5 & 1.5 & 6 & 6 & 24 & 24 \\
\hline Acetone Ext & 1.5 & 3 & 3 & 1.5 & 3 & 3 & 3 & 3 & 12 & 12 & 24 & 24 \\
\hline
\end{tabular}

Acetone Ext

Chloroform Ext

Hexane Ext

B. lacera

\begin{tabular}{|c|c|c|c|c|c|c|c|c|c|c|c|c|}
\hline Water Ext & 1.5 & 3 & 1.5 & 3 & 3 & 1.5 & 1.5 & 3 & - & - & - & 24 \\
\hline Methanol Ext & 6 & 6 & 3 & 6 & 6 & 3 & 6 & 6 & 6 & 6 & 24 & 24 \\
\hline Acetone Ext & 1.5 & 1.5 & 3 & 3 & 3 & 1.5 & 1.5 & 3 & - & - & - & - \\
\hline Chloroform Ext & - & - & - & - & - & - & - & - & - & - & - & - \\
\hline Hexane Ext & - & - & - & - & - & - & - & - & 12 & 12 & - & 24 \\
\hline \multicolumn{13}{|l|}{ B. eriantha } \\
\hline Water Ext & 0.75 & 3 & 1.5 & 3 & 3 & 1.5 & 1.5 & 3 & - & - & - & 12 \\
\hline Methanol Ext & 6 & 6 & 3 & 6 & 12 & 6 & 12 & 3 & - & - & - & - \\
\hline Acetone Ext & 1.5 & 1.5 & 6 & 3 & 3 & 1.5 & 3 & 1.5 & - & - & - & - \\
\hline Chloroform Ext & - & 1.5 & - & - & - & - & - & - & - & - & - & - \\
\hline Hexane Ext & - & - & - & - & - & - & - & - & 12 & 24 & - & 12 \\
\hline \multicolumn{13}{|l|}{ T. nerifolia } \\
\hline Water Ext & 1.5 & 1.5 & 0.75 & 3 & 0.75 & 1.5 & 1.5 & 1.5 & - & - & - & - \\
\hline Methanol Ext & 3 & 6 & 1.5 & 3 & 3 & 3 & 3 & 6 & 12 & 12 & 24 & 24 \\
\hline Acetone Ext & 0.75 & 0.75 & 3 & 3 & 1.5 & 1.5 & 3 & 3 & - & - & - & - \\
\hline Chloroform Ext & - & 3 & - & 3 & - & - & - & - & - & - & - & - \\
\hline Hexane Ext & 3 & - & 3 & - & - & 3 & - & - & 12 & 12 & 24 & 24 \\
\hline \multicolumn{13}{|c|}{ Bauhinia purpurea } \\
\hline Water Ext & - & 6 & 3 & 3 & 3 & 6 & 3 & 6 & 12 & 12 & 24 & 24 \\
\hline
\end{tabular}


Assessment of antimicrobial activity of hundreds extract of twenty Indian medicinal plants

\begin{tabular}{|c|c|c|c|c|c|c|c|c|c|c|c|c|}
\hline Methanol Ext & 6 & - & 6 & - & 3 & - & 6 & 6 & 3 & 3 & 3 & 1.5 \\
\hline Acetone Ext & - & - & 3 & 3 & 3 & 3 & 6 & 3 & 12 & 12 & 12 & 24 \\
\hline Chloroform Ext & 6 & 3 & 3 & 3 & - & - & - & 6 & 12 & 12 & 24 & 24 \\
\hline Hexane Ext & - & - & 3 & 3 & 3 & - & 3 & 3 & 3 & 3 & 3 & 3 \\
\hline \multicolumn{13}{|l|}{ J. gossypifolia } \\
\hline Water Ext & 24 & 24 & 24 & 12 & 24 & 12 & 24 & 12 & 24 & - & - & 24 \\
\hline Methanol Ext & 24 & 24 & 24 & 12 & 24 & 12 & 12 & 24 & 24 & 12 & 24 & 24 \\
\hline Acetone Ext & 24 & 24 & 12 & 12 & 24 & 24 & 24 & 12 & - & - & - & 24 \\
\hline Chloroform Ext & 12 & 12 & 24 & 12 & - & - & 12 & - & - & - & - & 24 \\
\hline Hexane Ext & 12 & 12 & 24 & 12 & 24 & 6 & 12 & 24 & - & - & - & 6 \\
\hline \multicolumn{13}{|l|}{ P. dulce } \\
\hline Water Ext & - & - & - & - & - & - & - & - & - & -- & - & - \\
\hline Methanol Ext & 24 & 24 & 24 & 12 & 24 & 12 & 12 & 24 & 24 & 12 & 24 & 24 \\
\hline Acetone Ext & - & - & - & - & - & - & - & - & - & - & - & - \\
\hline Chloroform Ext & 24 & 24 & 24 & 12 & 24 & 12 & 12 & - & - & - & - & - \\
\hline Hexane Ext & - & - & - & - & - & - & - & - & - & - & - & - \\
\hline \multicolumn{13}{|l|}{ H. integrifolia } \\
\hline Water Ext & 12 & 12 & 12 & 3 & 24 & 12 & 12 & 12 & 12 & 12 & 24 & 24 \\
\hline Methanol Ext & 6 & 6 & 3 & 6 & 12 & 6 & 12 & 3 & 6 & 12 & 3 & 24 \\
\hline Acetone Ext & - & - & - & - & - & - & - & - & - & - & - & - \\
\hline Chloroform Ext & 6 & 6 & 3 & 3 & 12 & 6 & 12 & 3 & 12 & 12 & 24 & 24 \\
\hline Hexane Ext & - & - & - & - & - & - & - & - & - & - & - & - \\
\hline \multicolumn{13}{|l|}{ Ketoconazole } \\
\hline \multicolumn{13}{|l|}{ Ampicillin } \\
\hline S. indicus & A & B & C & $\mathrm{D}$ & $\mathrm{E}$ & $\mathrm{F}$ & G & $\mathrm{H}$ & I & $\mathrm{J}$ & K & L \\
\hline Water Ext & 0.75 & 1.52 & 0.75 & 0.75 & 1.5 & 0.75 & 0.75 & 0.75 & 1.5 & 1.5 & 2.5 & 1.5 \\
\hline Methanol Ext & - & 1.52 & 6 & - & 3 & - & 6 & 6 & 3 & 3 & 3 & 1.5 \\
\hline Acetone Ext & -6 & 6 & 3 & 6 & 12 & 6 & 12 & 3 & - & - & - & - \\
\hline Chloroform Ext & 0.75 & 1.52 & 0.75 & 0.75 & 1.5 & 0.75 & 0.75 & 0.75 & 1.5 & 1.5 & 2.5 & 1.5 \\
\hline \multicolumn{13}{|l|}{ V. negundo } \\
\hline Water Ext & - & 6 & 3 & 3 & 3 & 6 & 3 & 6 & - & - & - & - \\
\hline Methanol Ext & 6 & 6 & 3 & 6 & 6 & 3 & 6 & 6 & 3 & 3 & 3 & 1.5 \\
\hline Acetone Ext & - & - & 3 & 3 & 3 & 3 & 6 & 3 & - & - & - & - \\
\hline Chloroform Ext & - & 3 & 3 & 3 & - & - & - & 6 & 6 & 12 & 6 & 12 \\
\hline Hexane Ext & 0.75 & 3 & 1.5 & 3 & 3 & 1.5 & 1.5 & 3 & 3 & 3 & 1.5 & - \\
\hline \multicolumn{13}{|l|}{ Z. xylopyrus } \\
\hline Water Ext & - & - & - & - & - & - & - & - & - & - & - & - \\
\hline Methanol Ext & 3 & 1.5 & 3 & 1.5 & 3 & 3 & 1.5 & 1.5 & 24 & 12 & 24 & 24 \\
\hline
\end{tabular}




\begin{tabular}{|c|c|c|c|c|c|c|c|c|c|c|c|c|}
\hline Acetone Ext & 1.5 & 3 & 3 & 1.5 & 3 & 3 & 3 & 3 & - & - & - & - \\
\hline Chloroform Ext & - & - & - & - & - & - & - & - & 24 & 12 & 24 & 12 \\
\hline Hexane Ext & 6 & 24 & 24 & 12 & 12 & 12 & 12 & 24 & - & & - & - \\
\hline \multicolumn{13}{|l|}{ A. heterophylum } \\
\hline Water Ext & 6 & 6 & 3 & 6 & 12 & 6 & 12 & 3 & - & - & - & 24 \\
\hline Methanol Ext & 1.5 & 1.5 & 3 & 3 & 3 & 1.5 & 1.5 & 3 & 1.5 & 1.5 & 2.5 & 1.5 \\
\hline Acetone Ext & 1.5 & 1.5 & 3 & 3 & 3 & 1.5 & 1.5 & 3 & - & - & - & - \\
\hline Chloroform Ext & - & - & - & - & - & - & - & - & - & - & & - \\
\hline Hexane Ext & - & - & - & - & - & - & - & - & 12 & 12 & - & 24 \\
\hline \multicolumn{13}{|l|}{ S. dulcis } \\
\hline Water Ext & 0.75 & 3 & 1.5 & 3 & 3 & 1.5 & 1.5 & 3 & - & - & - & 12 \\
\hline Methanol Ext & 6 & 6 & 3 & 6 & 12 & 6 & 12 & 3 & - & - & - & - \\
\hline Acetone Ext & 1.5 & 1.5 & 6 & 3 & 3 & 1.5 & 3 & 1.5 & - & - & - & - \\
\hline Chloroform Ext & - & 1.5 & - & - & - & - & - & - & - & - & - & - \\
\hline Hexane Ext & - & - & - & - & - & - & - & - & 12 & 6 & - & - \\
\hline \multicolumn{13}{|l|}{ C. dichtoma } \\
\hline Water Ext & 1.5 & 1.5 & 0.75 & 3 & 0.75 & 1.5 & 1.5 & 1.5 & - & - & - & - \\
\hline Methanol Ext & 3 & 6 & 1.5 & 3 & 3 & 3 & 3 & 6 & - & - & - & - \\
\hline Acetone Ext & 0.75 & 0.75 & 3 & 3 & 1.5 & 1.5 & 3 & 3 & - & - & - & - \\
\hline Chloroform Ext & 24 & 24 & 24 & 12 & 24 & 12 & 24 & 12 & - & - & - & - \\
\hline Hexane Ext & - & - & - & - & - & - & - & - & - & - & - & - \\
\hline \multicolumn{13}{|l|}{ A. zylamei } \\
\hline Water Ext & 24 & 24 & 24 & 12 & 24 & 12 & 24 & 12 & - & - & - & - \\
\hline Methanol Ext & 3 & 3 & 6 & 1.5 & 3 & 3 & 3 & 3 & 6 & 12 & 24 & 12 \\
\hline Acetone Ext & - & - & - & - & - & - & - & - & - & - & - & - \\
\hline Chloroform Ext & 24 & 24 & 24 & 12 & 24 & 12 & 12 & 24 & - & 12 & 24 & 12 \\
\hline Hexane Ext & 24 & 24 & 24 & 12 & 24 & 12 & 12 & 24 & - & - & - & - \\
\hline \multicolumn{13}{|l|}{ S. angustifolia } \\
\hline Water Ext & 24 & 24 & 24 & 12 & 12 & 12 & 24 & 12 & 12 & 24 & 24 & 24 \\
\hline Methanol Ext & 0.312 & 1.52 & 0.75 & 0.75 & 1.5 & 0.75 & 0.75 & 0.75 & 1.5 & 1.5 & 2.5 & 1.5 \\
\hline Acetone Ext & 24 & 24 & - & 12 & 24 & 24 & 24 & 12 & - & - & - & 24 \\
\hline Chloroform Ext & - & - & 12 & 12 & - & - & 12 & - & - & - & - & 24 \\
\hline Hexane Ext & 12 & 12 & 24 & 12 & 24 & 6 & 12 & 24 & - & - & - & 6 \\
\hline \multicolumn{13}{|l|}{ S. chirayita } \\
\hline Water Ext & - & - & - & - & - & - & - & - & - & - & - & - \\
\hline Methanol Ext & 24 & 24 & 24 & 12 & 24 & 12 & 6 & 6 & 6 & 6 & 24 & 24 \\
\hline Acetone Ext & - & - & - & - & - & - & - & - & - & - & - & - \\
\hline Chloroform Ext & 12 & 12 & 24 & 12 & 24 & 12 & 12 & - & - & - & - & - \\
\hline
\end{tabular}




\begin{tabular}{|c|c|c|c|c|c|c|c|c|c|c|c|c|}
\hline Hexane Ext & 12 & 3 & 6 & 1.5 & 3 & 3 & 3 & 3 & 6 & 12 & 24 & 12 \\
\hline \multicolumn{13}{|c|}{ A. heterophyllum } \\
\hline Water Ext & 12 & 12 & 24 & 12 & 24 & 12 & 24 & 12 & - & - & - & - \\
\hline Methanol Ext & 3 & 3 & 6 & 1.5 & 3 & 3 & 3 & 3 & 6 & 12 & 24 & 12 \\
\hline Acetone Ext & - & - & - & - & - & - & - & - & - & - & - & - \\
\hline Chloroform Ext & 24 & 24 & 24 & 12 & 24 & 12 & 12 & 24 & - & 12 & 24 & 24 \\
\hline Hexane Ext & 24 & 24 & 24 & 12 & 24 & 12 & 12 & 24 & - & - & - & - \\
\hline
\end{tabular}

Ketoconazole

Ampicillin

A: S. pyogenes; B: E. coli; C: S. typhi, D: P. aeruginosa; E: S. aureus; F: E. aerogenes; G: B. cereus; H: K. pneumonae; I: A. fumigatus; J: A. flavus; K: A. niger, L: C. albicans. Note: (-) means no activity.

In the present study, the concentration of the extract which forms the least zone of inhibition $(\sim 6.5 \mathrm{~mm}$ : diameter of disc was $6.0 \mathrm{~mm}$ ) was considered as MIC by disc diffusion assay. The MIC by disc diffusion assay of the bacteria and fungi listed in Table 2. Activity of various extracts was found to be ranged from 0.75 to $24.0 \mu \mathrm{g} / \mathrm{disc}$ against the tested bacterial species by disc diffusion method. Hexane extract of $P$. urinaria, B. lacerav $H$. integrifolia $P$. dulce and chloroform extract of $P$. urinaria, B. lacera and $B$. eriantha and water extract of. $P$. urinaria were not found active against any tested pathogen by DDA and MDA.

The 51 extracts of $P$. urinaria, B. lacera, B. eriantha, $T$. nerifolia, J. gossypifolia, $P$. dulce, $H$. integrifolia, $S$. indicus, $V$. negundo, Z. xylopyrus, A. heterophylum, S. dulcis C. dichtoma, A. zylamei, S. angustifolia, S. chirayita, A. heterophyllum were found to be inhibiting all the bacterial strains tested, in a range of $0.75-24 \mathrm{mg} / \mathrm{ml}$ by microbroth dilution assay and 6.24 to $48.0 \mathrm{mg} /$ disc by disc diffusion assay. The 37 extracts were found to be active against the fungal strains in arrange of 1.5 to $24.0 \mathrm{mg} / \mathrm{ml}$ by microbroth dilution assay. Other plant extracts also exhibited variable antimicrobial activity against one or more species of microorganisms. $T$. nerifolia is used with Cannabis sativa to treat urinary infections. B. lacera and $B$. eriantha are described in Ayurveda as anti-inflammatory, antipyretic and anthelmintic. Roots of these plants are used to cure the mouth disease.

Methanol extract of Blumea lacera, T. nerifolia, J. gossypifolia $S$. dulcis and $C$. dichtoma showed activity against all tested pathogen. Water methanol and aacitone extract of $B$. eriantha active against all tested bacterial stain in the rage of 0.750 $\mathrm{mg} / \mathrm{ml}$ to $24 \mathrm{mg} / \mathrm{ml}$. Water and chloroform extract of $P$. urinaria, chloroform extract of $B$. eriantha, water and hexane extract of $P$. dulce. Hexane extract of $H$. integrifolia chloroform extract of heterophylum, Hexane extract of $C$. dichtoma and extract of $S$. chirayita does not show any activity.

S. xanthocapum and Bauhinia purpurea showed antifungal activity in water methanol acetone chloroform and hexane extractions. Water, methanol and chloroform extraction of Symplocos racemosa, methanol and acetone extraction of $P$. urinaria. Methanol extraction of $B$. lacera hexane extraction of $B$. eriantha. Methanol extraction of $T$. nerifolia and $J$. gossypifolia. Water and methanol extraction of $H$. integrifolia and $S$. indicus and methanol and chloroform extraction of $V$. negundo showed antifungal activity in the range of $750 \mathrm{mg} / \mathrm{ml}$ to $24 \mathrm{mg} / \mathrm{ml}$.

\section{Conclusion}

The available antibiotics become resistant to day by day to the microbial diseases and crucial need to determine new antimicrobial compounds with various chemical structure and novel mechanism of action for new and reemerging infectious disease. In this attempt, folkloric herbal drugs must necessarily to be approved the advantage of modern science and technology to serves further global needs. The drugs derived from herbs have the opportunity of using in medication because of its good antimicrobial activity as well as less toxic effects. An innovative drug should not comprise any toxic side effects, Hence the present study aimed to focus the antimicrobial activity of plants on tested pathogens which showed significant activity.

\section{Acknowledgements}

The author gratefully acknowledges Dr. Vinod Kumar Tiwari, Department of Chemistry, Banaras Hindu university, Varanasi India; Prof. Amita Jain, Department of Microbiology King George's Medical University, Lucknow, India; Dr. Rambir Singh, Institute of Biomedical sciences, Bundelkhand University Jhansi India; Dr. Rajesh Dabur, Department of Biochemistry MDU, Rohtak, Prof. S. L. Kothari and Prof. Ajay Jain, Amity Institute of Biotechnology, Amity University Rajasthan, India and finally with all centers of whole research and technical staff members for their wonderful lab support without any of them this work was not possible for me.

\section{References}

1. Yadav RK, Anand P. Aromatic medicinal plant resources in Uttar Pradesh, India. Med Aromat Plants 2014; 3: 3. 
2. Mishra BB, Singh DD, Kishore N, Tiwari VK, Tripathi V. Novel antifungal constituents isolated from the seeds of Aegle marmelos Corr. collected in India. Phytochem 2010; 71: 230-234.

3. Pandey A. A less known edible tree, Lauka (Crescentiacujeti) from Uttar Pradesh, India. J Eco Tax Bot 2002; 3: 662-664.

4. Singh DD, Khare M, Singh V. Molecular characterization of azole resistance mechanisms in Candida albicans clinical isolates from HIV-infected patients in India. Intern J Pharm Sci Res2014; 5: 3924-3931.

5. Singh DD, Singh V. In-vitro sensitivity of amphotericin B, itraconazole and fluconazole-resistant against Candida albicans. Intern J Pharm Sci Res 2011; 2: 1000-1004.

6. Singh DD, Singh V. Analysis of molecular resistance mechanisms of itraconazole in Candida albicans clinical isolates from India. Intern J Pharmac Sci Rev Res 2011; 1: 75-79.

7. Singh DD, Singh SP. In-vitro Antibiotic susceptibility investigation on probiotic Lactobacillus Johnsonii. J Chem Tracks 2007; 9: 111-114.

8. Singh DD, Singh R, Tiwari VK, Mishra BB. Antimicrobial activity studies on 1-cyclopropyl-2-ethyl-5floro-6-(4methylpiperazine-1-yl)-1H-bezimidazole. J Chem Tracks 2007; 9: 97-100.
9. Mishra BB, Kishore N, Tiwari VK, Singh DD, Tripathi V. A novel antifungal anthraquinone from seeds of Aegle marmelos Correa family Rutaceae). J Fitoth 2010; 81: 104-107.

10. Dabur R, Gupta A, Mondal TK, Singh DD, Bajpai V, Gurav AM, Lavekar GS. Antimicrobial activity of some Indian medicinal plant. Afri J Trad Med 2007; 4: 313-318.

11. Biswas TK, Mukherjee B. Plant medicines of Indian origin for wound healing activity: a review. Int J Low Extrem Wounds 2003; 2: 24-39.

12. National Committee for Clinical Laboratory Standards. Reference method for broth dilution antifungal susceptibility testing of yeasts; approved standard. M27-A. National Committee for Clinical Laboratory Standards, Wayne, Pa 2011.

13. Indian Pharmacopoeia. Microbiological assays and tests. Appendix 1996; 9: 100-108.

\section{*Correspondence to}

Desh Deepak Singh

Amity Institute of Biotechnology

Amity University

India 